\title{
BELANJA DAERAH SEBAGAI UPAYA MENGATASI KEMISKINAN DAN PENGANGGURAN DI KOTA BANJARMASIN
}

\author{
Isra U1 Huda ${ }^{1)}$ Anthonius J. Karsudjono ${ }^{2)}$ \\ e-mail: israulhuda83@gmail.com \\ Sekolah Tinggi Ilmu Ekonomi Pancasetia Banjarmasin
}

\begin{abstract}
Abstrak:
Penelitian ini bertujuan untuk mengetahui dan juga menganalisa Belanja Daerah Sebagai Upaya Mengatasi Kemiskinan Dan Pengangguran Kota Banjarmasin. Penelitian ini menggunakan metode analisa data kuantitatif. Hasil analisis yang dilakukan membuktikanBelanja pegawai pada tahun 2012 sampai dengan 2019 belum mampu mengatasi atau menurunkan angka kemiskinan di Kota Banjarmasin.Belanja Barang Jasa pada tahun 2012 sampai dengan 2019 belum mampu mengatasi atau menurunkan angka kemiskinan di Kota Banjarmasin.Belanja Modal pada tahun 2012 sampai dengan 2019 belum mampu mengatasi atau menurunkan angka kemiskinan di Kota Banjarmasin.Belanja pegawai pada tahun 2012 sampai dengan 2019 belum mampu mengatasi atau menurunkan angka pengangguran di Kota Banjarmasin.Belanja Barang Jasa pada tahun 2012 sampai dengan 2019 mampu mengatasi atau menurunkan angka pengangguran di Kota Banjarmasin.Belanja Modal pada tahun 2012 sampai dengan 2019 belum mampu mengatasi atau menurunkan angka pengangguran di Kota Banjarmasin.
\end{abstract}

Kata Kunci: Belanja Pegawai, Belanja Barang Jasa, Belanja Modal, Kemiskinan, Pengangguran 


\section{PENDAHULUAN}

Masalah kemiskinan dianggap sebagai salah satu hal yang menghambat proses pembangunan sebuah negara. Salah satu negara yang masih dibelit oleh masalah sosial ini adalah Indonesia. Kemiskinan menurut World Bank (WB) merupakan keadaan dimana seorang atau kelompok yang tidak memiliki pilihan-pilihan atau peluang untuk meningkatkan taraf hidupnya guna menjalani kehidupan yang sehat dan lebih baik sesuai standar hidup, memiliki harga diri dan dihargai oleh sesamanya, sedangkan menurut Badan Pusat Statistik (BPS) bahwa kemiskinan merupakan keadaan dimana seseorang tidak mampu memenuhi kebutuhan dasarnya seperti pakaian, tempat tinggal, makanan, pendidikan dan kesehatan yang dianggap sebagai kebutuhan dan memiliki standar tertentu dan diukur melalui sisi pengeluaran.

Berdasarkan data, bahwa jumlah penduduk miskin Kota Banjarmasin sejak periode tahun 2012 s/d 2019 cenderung mengalami kenaikan dari tahun ke tahun, hanya terjadi penurunan pada tahun 2013 menjadi 27.777 jiwa dan tahun 2016 menjadi 28.750. Selama empat tahun terakhir sepertinya terjadi masa-masa sulit bagi warga Kota Banjarmasin yang tergambar dari meningkatnya jumlah penduduk miskin dari tahun 2016 s/d 2019 dimana pada tahun 2019 sudah mencapai 29.648 jiwa, sedangkan pada tahun 2016 masih 28.750 jiwa. Dengan data-data tersebut menjadikan Kota Banjarmasin menjadi penyumbang penduduk miskin terbanyak di Kalimantan Selatan setiap tahunnya. Meningkatnya jumlah penduduk miskin ini, pemerintah kota menduga salah satunya karena meningkat pula musibah kebakaran di Banjarmasin.

Selain kemiskinan yang tidak kalah penting adalah persoalan pengangguran. Menurut Badan Pusat Statistik (BPS) dalam indikator ketenagakerjaan, pengangguran dapat diartikan sebagai penduduk yang tidak bekerja namun sedang mencari pekerjaan atau sedang mempersiapkan suatu usaha baru atau penduduk yang tidak mencari pekerjaan karena sudah diterima bekerja tetapi belum mulai bekerja. 
Masalah ketenagakerjaan merupakan masalah yang sangat rumit di dalam pembangunan ekonomi, sehingga memerlukan penanganan khusus. Keadaan yang tidak seimbang antara kemampuan negara berkembang untuk menyediakan lapangan pekerjaan dan jumlah tenaga kerja yang selalu bertambah dari waktu ke waktu menimbulkan implikasi semakin tingginya angka pengangguran. Berdasarkan data yang diperoleh bahwa perkembangan jumlah pengangguran di Kota Banjarmasin sejak periode tahun 2012 s/d 2019 mengalami kenaikan sejak tahun 2013 kemudian turun kembali sejak tiga tahun takhir pada 2017, dan jumlah pengangguran tertinggi terdeteksi terjadi pada tahun 2016 sebesar 32.674 jiwa kemudian terendah terjadi pada tahun 2013 sebesar 15.114 jiwa. Berdasarkan data-data tersebut pula, menjadikan Kota Banjarmasin sebagai penyumbang jumlah pengangguran terbanyak di Kalimantan Selatan, dengan demikian hal ini semakin menguatkan anggapan bahwa kota besar identik dengan sulitnya mencari pekerjaan.

Kebijakan pemerintah daerah dalam bentuk kebijakan fiskal melalui pengeluaran pemerintah daerah berupa belanja langsung dan belanja tidak langsung diharapkan dapat menanggulangi masalah kemiskinan dan juga pengangguran sehingga angka kemiskinan dan juga pengangguran khususnya di Kota Banjarmasin dapat mengalami penurunan. Belanja daerah, atau yang dikenal dengan pengeluaran pemerintah daerah dalam anggaran pendapatan dan belanja daerah (APBD), merupakan salah satu faktor pendorong pertumbuhan ekonomi daerah. Karena itu, belanja daerah dikenal sebagai salah satu instrumen kebijakan fiskal yang dilakukan pemerintah (pemerintah daerah), di samping pos pendapatan pemerintah daerah. Marsye H. Kaat, Paulus Kindangen, Debby Ch. Rotinsulu (2016)

Pengeluaran pemerintah daerah melalui belanja langsung maupun belanja tidak langsung merupakan alat intervensi pemerintah terhadap perekonomian yang dianggap paling efektif, selain kemampuan intervensi lainnya dari pemerintah. 
Keberhasilan suatu daerah dalam mewujudkan kesejahteraan masyarakat sangat tergantung pada kebijakan pemerintah daerah melalui alokasi belanjanya. Alokasi belanja yang baik tentunya diharapkan dapat meningkatkan kesejahteraan masyarakatnya.

\section{TINJAUAWAN PUSTAKA}

\section{Belanja Pegawai}

Berdasarkan Peraturan Menteri Dalam Negeri Nomor 58 Tahun 2005 tentang Pedoman Pengelolaan Keuangan Daerah. Belanja pegawai dalam kelompok belanja langsung tersebut dimaksudkan untuk pengeluaran honorarium/upah dalam melaksanakan program dan kegiatan pemerintahan daerah. Belanja jenis ini antara lain untuk menampung honorarium panitia pengadaan dan administrasi pembelian/ pembangunan untuk memperoleh setisp aset yang dianggarkan pada belanja modal sebagaimana dianggarkan pada belanja pegawai dan/atau belanja barang dan jasa

\section{Belanja Barang Jasa}

Berdasarkan Peraturan Menteri Dalam Negeri Nomor 58 Tahun 2005 tentang Pedoman Pengelolaan Keuangan Daerah. Belanja barang dan jasa adalah pengeluaran untuk menampung pembelian barang dan jasa yang habis pakai untuk memproduksi barang dan jasa yang dipasarkan maupun tidak dipasarkan, dan pengadaan barang yang dimaksudkan untuk diserahkan untuk dijual kepada masyarakat dan belanja perjalanan

\section{Belanja Modal}

Berdasarkan Peraturan Menteri Dalam Negeri Nomor 58 Tahun 2005 tentang Pedoman Pengelolaan Keuangan Daerah. Belanja Modal adalah pengeluaran anggaran untuk perolehan aktiva tetap dan aset lainnya yang memberi manfaat lebih dari satu periode akuntansi. Untuk mengetahui apakah suatu belanja dapat dimasukkan sebagai 
belanja modal atau tidak, maka perlu diketahui definisi aset tetap atau aset lainnya dan kriteria kapitalisasi aset tetap

\section{Kemiskinan}

Kemiskinan menurut World Bank adalah keadaan dimana seorang atau kelompok yang tidak memiliki pilihan pilihan atau peluang untuk meningkatkan taraf hidupnya guna menjalani kehidupan yang sehat dan lebih baik sesuai standar hidup, memiliki harga diri dan dihargai oleh sesamanya, sedangkan menurut Badan Pusat Statistik bahwa kemiskinan merupakan keadaan dimana seseorang tidak mampu memenuhi kebutuhan dasarnya seperti pakaian, tempat tinggal, makanan, pendidikan dan kesehatan yang dianggap sebagai kebutuhan dan memiliki standar tertentu dan diukur melalui sisi pengeluaran.

World Bank (2008) menghitung tingkat dan jumlah penduduk miskin absolut dengan menggunakan ukuran tunggal yang seragam untuk semua negara. Di negaranegara sedang berkembang seseorang disebut miskin bila berpendapatan kurang dari \$ US 1 per hari, dimana diperkirakan ada sekitar 1,2 milyar penduduk dunia yang hidup dibawah ukuran tersebut. Sementara garis kemiskinan yang diukur berdasarkan ukuran \$ US 2 juga telah dipublikasikan dimana lebih dari 2 milyar penduduk yang hidup kurang dari batas tersebut. US dolar yang digunakan adalah US \$ PPP (Purchasing Power Parity) bukan nilai tukar resmi (exchange rate). Kedua batas ini adalah garis kemiskinan absolut

Menurut BPS untuk mengukur kemiskinan, BPS menggunakan konsep kemampuan memenuhi kebutuhan dasar (basic needs approach). Dengan pendekatan ini, kemiskinan dipandang sebagai ketidakmampuan dari sisi ekonomi untuk memenuhi kebutuhan dasar makanan dan bukan makanan yang diukur dari sisi pengeluaran.

Jadi Penduduk Miskin adalah penduduk yang memiliki rata-rata pengeluaran perkapita perbulan dibawah garis kemiskinan. Berikut konsep garis kemiskinan: 
a. Garis Kemiskinan (GK) merupakan penjumlahan dari Garis Kemiskinan Makanan (GKM) dan Garis Kemiskinan Non Makanan (GKNM). Penduduk yang memiliki rata-rata pengeluaran perkapita per bulan dibawah Garis Kemiskinan dikategorikan sebagai penduduk miskin.

b. Garis Kemiskinan Makanan (GKM) merupakan nilai pengeluaran kebutuhan minimum makanan yang disetarakan dengan 2100 kilokalori perkapita perhari. Paket komoditi kebutuhan dasar makanan diwakili oleh 52 jenis komoditi (padipadian, umbi-umbian, ikan, daging, telur dan susu, sayuran, kacang-kacangan, buah-buahan, minyak dan lemak, dll)

c. Garis Kemiskinan Non Makanan (GKNM) adalah kebutuhan minimum untuk perumahan, sandang, pendidikan dan kesehatan. Paket komoditi kebutuhan dasar non makanan diwakili oleh 51 jenis komoditi di perkotaan dan 47 jenis komoditi di pedesaan.

Rumus Penghitungan:

$$
\begin{aligned}
& \text { GK }=\text { GKM }+ \text { GKNM } \\
& \text { GK }=\text { Garis Kemiskinan } \\
& \text { GKM }=\text { Garis Kemiskinan Makanan } \\
& \text { GKNM = Garis Kemiskinan Non Makan }
\end{aligned}
$$

\section{Pengangguran}

Menurut Badan Pusat Statistik (BPS) dalam indikator ketenagakerjaan, pengangguran adalah penduduk yang tidak bekerja namun sedang mencari pekerjaan atau sedang mempersiapkan suatu usaha baru atau penduduk yang tidak mencari pekerjaan karena sudah diterima bekerja tetapi belum mulai bekerja.

Menurut Sukirno (1994), pengangguran adalah suatu keadaan dimana seseorang yang termasuk dalam angkatan kerja ingin memperoleh pekerjaan akan tetapi belum mendapatkannya. Seseorang yang tidak bekerja namun tidak secara aktif mencari 
pekerjaan tidak tergolong sebagai pengangguran. Fator utama yang menyebabkan terjadinya pengangguran adalah kurangnya pengeluaran agregat. Pengusaha memproduksi barang dan jasa dengan maksud memperoleh keuntungan, akan tetapi keuntungan tersebut akan diperoleh apabila pengusaha tersebut dapat menjual barang dan jasa yang mereka produksi. Semakin besar permintaan, semakin besar pula barang dan jasa yang mereka wujudkan. Kenaikan produksi yang dilakukan akan menambah penggunaan tenaga kerja.

Beberapa akibat buruk dari pengangguran dibedakan kepada dua aspek (Sukirno,2000) dimana dua aspek tersebut yaitu :

a. Akibat buruk terhadap kegiatan perekonomian

Tingkat pengangguran yang relatif tinggi tidak memungkinkan masyarakat mencapai pertumbuhan ekonomi yang tangguh. Hal ini dapat dengan jelas dilihat dari berbagai akibat buruk yang bersifat ekonomi yang ditimbulkan oleh masalah pengangguran. Akibat-akibat buruk tersebut dapat dibedakan sebagai berikut :

1) Pengangguran menyebabkan tidak memaksimalkan tingkat kemakmuran yang mungkin dicapainya

2) Pengangguran menyebabkan pendapatan pajak pemerintah berkurang. Pengangguran diakibatkan oleh tingkat kegiatan ekonomi yang rendah, dan dalam kegiatan ekonomi yang rendah pendapatan pajak pemerintah semakin sedikit.

3) Pengangguran tidak menggalakkan pertumbuhan ekonomi. Pengangguran menimbulkan dua akibat buruk kepada kegiatan sektor swasta. Yang pertama, pengangguran tenaga buruh diikuti pula oleh kelebihan kapasitas mesin-mesin perusahaan. Kedua, pengangguran yang diakibatkan oleh keuntungan kelesuan kegiatan perusahaan yang rendah menyebabkan berkurangnya keinginan untuk melakukan investasi. 
b. Akibat buruknya terhadap individu dan masyarakat

Pengangguran akan mempengaruhi kehidupan individu dan kestabilan sosial dalam masyarakat. Beberapa keburukan sosial yang diakibatkan oleh pengangguran adalah :

1) Pengangguran menyebabkan kehilangan mata pencaharian dan pendapatan.

2) Pengangguran dapat menyebabkan kehilangan keterampilan. Keterampilan dalam mengerjakan suatu pekerjaan hanya dapat dipertahankan apabila keterampilan tersebut digunakan dalam praktek

3) Pengangguran dapat menyebabkan ketidakstabilan sosial dan politik. Kegiatan ekonomi yang lesu dan pengangguran yang tinggi dapat menimbulkan rasa tidak puas masyarakat terhadap pemerintah

\section{Penelitian Terdahulu}

Fasholla (2018) melakukan penelitian tentang Pengaruh Belanja Daerah, Jumlah Penduduk, dan Pendapatan Asli Daerah Terhadap Jumlah Kemiskinan Di Kabupaten Cilacap. Data yang digunakan dalam penelitian ini adalah data panel yaitu gabungan antara data time series dan data cross section dari tahun 2011 hingga 2016. Hasil penelitian ini menunjukkan Belanja Daerah berpengaruh positif terhadap Jumlah Kemiskinan.

Rotinsulu et. al, (2015) meneliti tentang Analisis Dampak Anggaran Pendapatan dan Belanja Derah Terhadap Pertumbuhan Ekonomi, Kemiskinan dan Pengagguran Di Sulawesi Utara. Penelitian ini bertujuan untuk melihat seberapa pengaruh pemerintah melalui APBD nya dalam meningkatkan pertumbuhan, menekan angka pengangguran dan mengurangi kemiskinan di Kabupaten, Kota di wilayah Sulawesi Utara. Hasil penelitian ini menunjukkan bahwa di kota Manado alokasi Anggaran Pendapatan dan Belanja Daerah (APBD) tidak memberi pengaruh yang signifikan terhadap pertumbuhan ekonomi, penurunan angka kemiskinan serta penurunan tingkat 
pengangguran. Di kota Bitung pengaruh APBD terhadap perekonomian masih amat besar bahkan berdasarkan hasil penelitian didapatkan hasil bahwa baik pertumbuhan ekonomi, pengangguran maupun tingkat kemiskinan. Di Minahasa APBD tidak memberi pengaruh pada perekonomian, baik dalam pertumbuhan ekonomi, penurunan angka kemiskinan dan penurunan angka pengangguran. Di Kabupaten Bolaang Mongondouw alokasi anggaran APBD kurang memberi pengaruh yang positif dan signifikan terhadap penurunan angka kemiskinan, serta angka pengangguran yang ada di Bolaang Mongondouw.

Rudiningtyas (2009) meneliti tentang Pengaruh Pendapatan dan Belanja Terhadap Pertumbuhan Ekonomi, Kemiskinan dan Pengangguran. Hasil penelitian ini menunjukkan bahwa pendapatan dan belanja tidak berpengaruh terhadap kemiskinan selama tahunanggaran 2004 sampai dengan 2008 serta pendapatan dan belanja tidak berpengaruh terhadappengangguran selama tahun anggaran 2004 sampai dengan 2008.

Iskana (2009) meneliti tentang Pengaruh Belanja dan PendapatanTerhadap Pertumbuhan Ekonomi, Kemiskinan Dan Pengangguran padaPemerintahan Kabupaten dan Kota Provinsi Jawa Timur. Hasil penelitianmenunjukkan Belanja Daerah tidak berpengaruh signifikan terhadappertumbuhan ekonomi, belanja daerah berpengaruh positif dan signifikanterhadap kemiskinan, belanja daerah berpengaruh positif dan signifikanterhadap pengangguran. 


\section{Kerangka Model Penelitian}

Gambaran singkat dari penelitian ini dapat dilihat di kerangka konseptual dibawah ini :

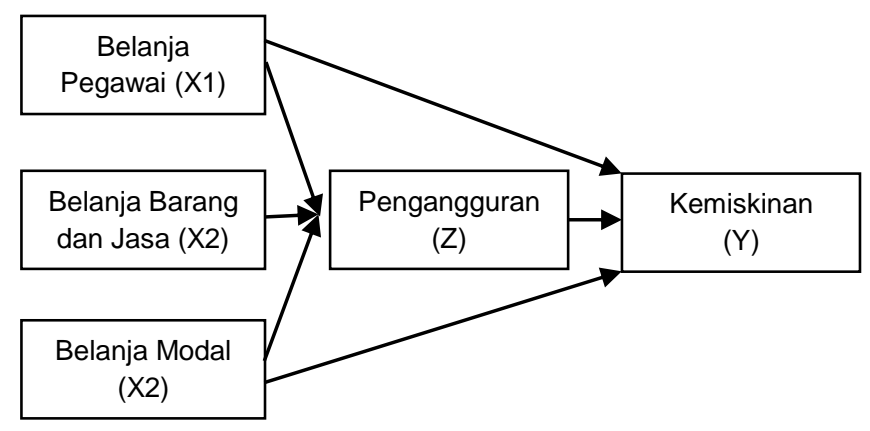

\section{Gambar 1 :KerangkaKonseptual}

\section{Pengujian Hipotesis}

Pengujian hipotesis dilakukan dengan menggunakan penilaian sebagai berikut sebagai berikut (Noor, 2014):

a. Dalam penelitian ini untuk pengaruh secara langsung (direct effect) dilakukan dengan melihat nilai p-value dengan tingkat signifikansi 0,05 ( $\alpha=5 \%)$ dengan kriteria pengujian:

- Apabila p-value> 0,05 maka $\mathrm{H}_{0}$ diterima dan $\mathrm{H}_{1}$ ditolak, berarti tidak ada pengaruh yang signifikan antara variabel eksogen dengan variabel endogen.

- Apabila p-value < 0,05 maka $\mathrm{H}_{0}$ ditolak dan $\mathrm{H}_{1}$ diterima, berarti ada pengaruh yang signifikan antara variabel eksogen dengan variabel endogen.

b. Dalam penelitian ini untuk pengaruh secara tidak langsung (indirect effect) dilakukan dengan membandingkan koefisien jalur langsung dan tidak langsung dengan kriteria pengujian (Sunyoto, 2012): 
- Apabila koefisien jalur langsung > koefisien jalur tidak langsung maka $\mathrm{H}_{0}$ diterima dan $\mathrm{H}_{1}$ ditolak, berarti tidak ada pengaruh yang signifikan antara variabel eksogen dengan variabel endogen.

- Apabila koefisien jalur langsung < koefisien jalur tidak langsung $\mathrm{H}_{0}$ ditolak dan $\mathrm{H}_{1}$ diterima, berarti ada pengaruh yang signifikan antara variabel eksogen dengan variabel endogen.

\section{METODE PENELITIAN}

Jenis penelitian ini adalah penelitian deskriptif kuantitatif. Menurut Mudrajat Kuncoro(2007), penelitian deskriptif merupakan pengumpulan data untuk diuji hipotesis atau menjawab pertanyaan mengenai status terakhir dari subjek penelitian. Tujuan dari penelitian kuantitatif adalah mengembangkan dan menggunakan modelmodel matematis, teori-teori, dan hipotesis yang berkaitan dengan fenomena lain.

\section{HASIL PENELITIAN DAN PEMBAHASAN}

\section{HASIL PENELITIAN}

\section{Deskripsi Variabel Penelitian}

Berikut ini merupakan gambaran singkat perkembangan belanja pegawai, belanja barang jasa, belanja modal, kemudian angka kemiskinan dan juga pengangguran sebagai variabel penelitian, adalah sebagai berikut:

\section{Kemiskinan}

Menurut Badan Pusat Statistik (BPS) bahwa kemiskinan merupakan keadaan dimana seseorang tidak mampu memenuhi kebutuhan dasarnya seperti pakaian, tempat tinggal, makanan, pendidikan dan kesehatan yang dianggap sebagai kebutuhan dan memiliki standar tertentu dan diukur melalui sisi pengeluaran. Berikut ini merupakan perkembangan jumlah kemiskinan Kota Banjarmasin sejak 8 (delapan) tahun terakhir periode 2012 s/d 2019 yang dapat dilihat pada grafik dan tabel di bawah ini. 


\section{Kemiskinan}

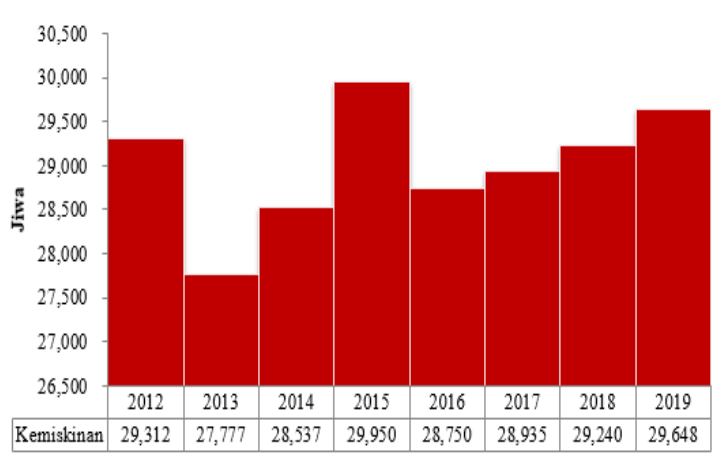

Sumber : Diolah, 2020

Gambar 2 : Kemiskinan

Berdasarkan grafik di atas dapat dilihat bahwa jumlah penduduk miskin Kota Banjarmasin sejak periode tahun 2012 s/d 2019 cenderung mengalami kenaikan dari tahun ke tahun, hanya terjadi penurunan pada tahun 2013 menjadi 27.777 jiwa dan tahun 2016 menjadi 28.750. Selama empat tahun terakhir sepertinya terjadi masamasa sulit bagi warga Kota Banjarmasin yang tergambar dari meningkatnya jumlah penduduk miskin dari tahun 2016 s/d 2019 dimana pada tahun 2019 sudah mencapai 29.648 jiwa, sedangkan pada tahun 2016 masih 28.750 jiwa. Dengan data-data tersebut menjadikan Kota Banjarmasin menjadi penyumbang penduduk miskin terbanyak di Kalimantan Selatan setiap tahunnya. Meningkatnya jumlah penduduk miskin ini, pemerintah kota menduga salah satunya karena meningkat pula musibah kebakaran di Banjarmasin.

\section{Pengangguran}

Menurut Badan Pusat Statistik (BPS) dalam indikator ketenagakerjaan, pengangguran dapat diartikan sebagai penduduk yang tidak bekerja namun sedang mencari pekerjaan atau sedang mempersiapkan suatu usaha baru atau penduduk yang tidak mencari pekerjaan karena sudah diterima bekerja tetapi belum mulai 
bekerja. Berikut ini merupakan perkembangan jumlah pengangguran Kota Banjarmasin sejak 8 (delapan) tahun terakhir periode 2012 s/d 2019 yang dapat dilihat pada grafik dan tabel di bawah ini.

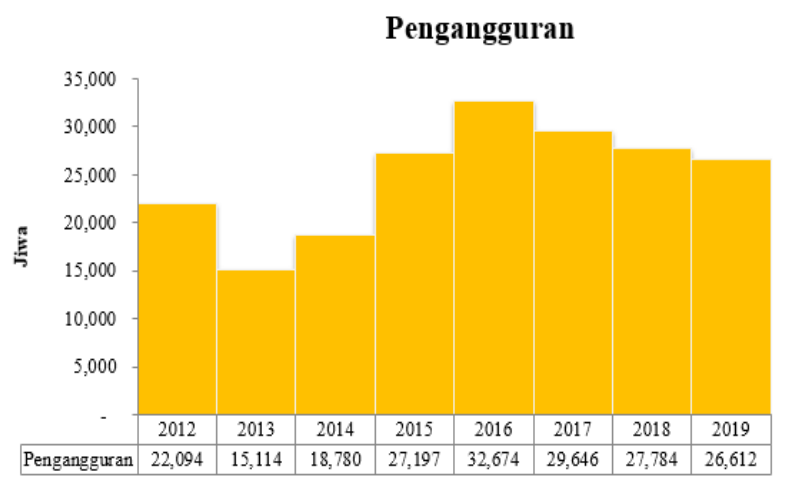

Sumber : Diolah, 2020

Gambar 3 : Pengangguran

Berdasarkan grafik di atas dapat dilihat bahwa perkembangan jumlah pengangguran di Kota Banjarmasin sejak periode tahun 2012 s/d 2019 mengalami kenaikan sejak tahun 2013 kemudian turun kembali sejak tiga tahun takhir pada 2017, dan jumlah pengangguran tertinggi terdeteksi terjadi pada tahun 2016 sebesar 32.674 jiwa kemudian terendah terjadi pada tahun 2013 sebesar 15.114 jiwa. Berdasarkan data-data tersebut pula, menjadikan Kota Banjarmasin sebagai penyumbang jumlah pengangguran terbanyak di Kalimantan Selatan, dengan demikian hal ini semakin menguatkan anggapan bahwa kota besar identik dengan sulitnya mencari pekerjaan.

\section{Belanja Pegawai}

Belanja Pegawai merupakan belanja yang digunakan untuk membiayai kompensasi dalam bentuk uang atau barang yang diberikan kepada pegawai pemerintah pusat, pensiunan, anggota Tentara Nasional Indonesia/Kepolisian Negara Republik Indonesia dan pejabat negara, baik yang bertugas di dalam negeri 
maupun di luar negeri, sebagai imbalan atas pekerjaan yang telah dilaksanakan kecuali pekerjaan yang berkaitan dengan pembentukan modal. Berikut ini merupakan perkembangan realisasi belanja pegawai Kota Banjarmasin sejak 8 (delapan) tahun terakhir periode 2012 s/d 2019 yang dapat dilihat pada grafik dan tabel di bawah ini.

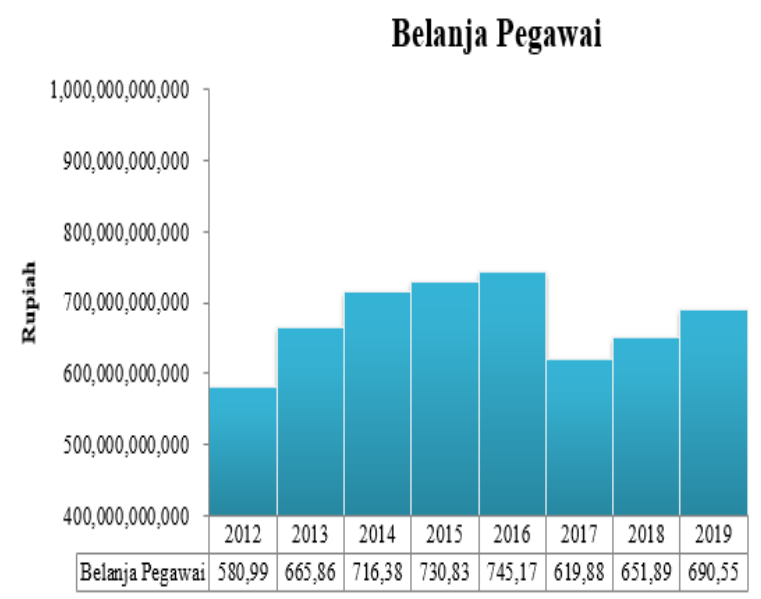

Berdasarkan grafik di atas dapat dilihat bahwa perkembangan realisasi belanja pegawai Kota Banjarmasin sejak periode tahun 2012 s/d 2019 cenderung mengalami kenaikan dari tahun ketahun, hanya terjadi penurunan pada tahun 2017 menjadi Rp. 619.886.021.594 dari tahun 2016 yaitu sebesar Rp. 745.179.135.248 yang sekaligus menjadikan tahun belanja pegawai tertinggi. Secara umum dari tahun ketahun realisasi belanja pegawai ini rata-rata menghabiskan hampir separuhnya dari APBD Kota Banjarmasin dan mendominasi dari anggaran belanja tidak langsung lainnya seperti hibah, bantuan sosial dsb.

\section{Belanja Barang dan Jasa}

Belanja Barang merupakan pengeluaran dalam rangka pembelian barang dan/atau jasa yang habis pakai untuk memproduksi barang dan/atau jasa yang dipasarkan maupun yang tidak dipasarkan serta pengadaan barang yang dimaksudkan

63

Jurnal Komunikasi Bisnis dan Manajemen

Vol. 8 No. 2 Juli 2021 
untuk diserahkan atau dijual kepada masyarakat di luar kriteria belanja bantuan sosial serta belanja perjalanan. Berikut ini merupakan perkembangan realisasi belanja barang dan jasa Kota Banjarmasin sejak 8 (delapan) tahun terakhir periode 2012 s/d 2019 yang dapat dilihat pada grafik dan tabel di bawah ini.

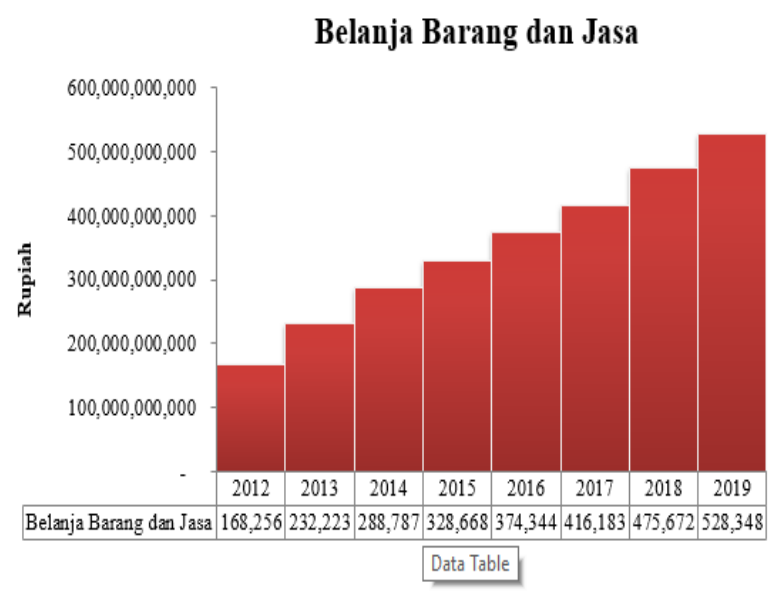

Gambar 5 : Belanja Barang dan Jasa

Sumber : Diolah, 2020

Berdasarkan grafik di atas dapat dilihat bahwa perkembangan realisasi belanja barang dan jasa Kota Banjarmasin sejak periode tahun 2012 s/d 2019 selalu mengalami kenaikan dari tahun ketahun. Belanja barang dan jasa terendah terjadi pada tahun 2012 sebesar RP. 168.256.481.155 serta tertinggi terjadi pada tahun 2019 sebesar Rp. 528.348.793.047. Semakin meningkatnya realisasi belanja barang dan jasa pemerintah kota ini, dapat diartikan bahwa pengadaan barang dan jasa pemerintah semakin meningkat pula dan inidapat berdampak pada pelayanan public yang semakin baik, sehingga pada akhirnya dapat mendorong laju pertumbuhan dan pemerataan ekonomi.

64 


\section{Belanja Modal}

Belanja modal merupakan pengeluaran untuk membayar perolehan aset dan/atau menambah nilai aset tetap/aset lainnya yang memberi manfaat lebih dari satu periode akuntansi dan melebihi batas minimal kapitalisasi aset tetap/aset lainnya yang ditetapkan pemerintah. Belanja ini terdiri dari belanja modal tanah, Belanja modal peralatan dan mesin, Belanja modal gedung dan bangunan, Belanja modal jalan, irigasi, dan jaringan, Belanja modal lainnya, Belanja modal Badan Layanan Umum (BLU). Berikut ini merupakan perkembangan realisasi belanja modal Kota Banjarmasin sejak 8 (delapan) tahun terakhir periode 2012 s/d 2019 yang dapat dilihat pada grafik dan tabel di bawah ini.

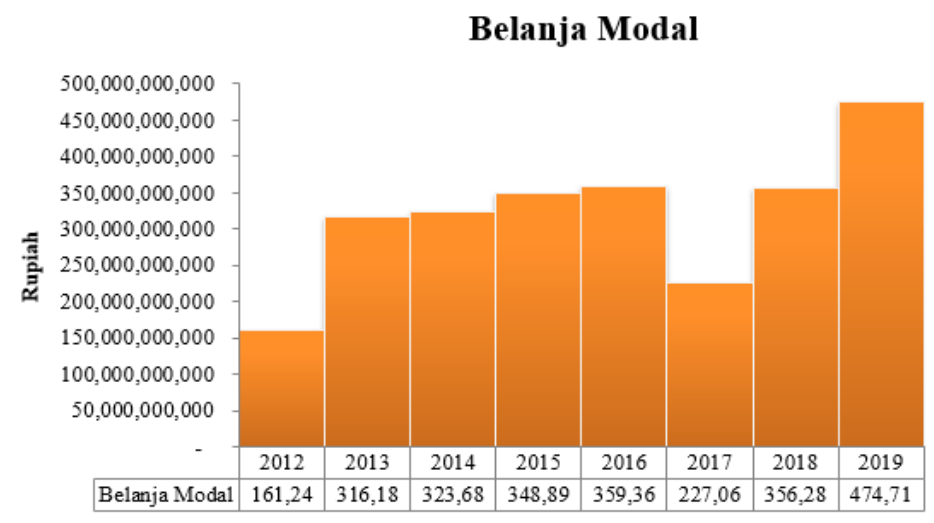

Sumber : Diolah, 2020

Gambar 6 : Belanja Modal

Berdasarkan grafik di atas dapat dilihat bahwa perkembangan realisasi belanja modal Kota Banjarmasin sejak periode tahun 2012 s/d 2019 cenderung mengalami kenaikan dari tahun ketahun, hanya terjadi penurunan pada tahun 2017 menjadi Rp. 227.067.328.775 dan belanja modal tertinggi terjadi pada tahun 2019 yaitu sebesar Rp. 474.715.262.744 serta yang terendah terjadi pada tahun 2012 sebesar Rp. 161.246.715.684. Semakin meningkatnya belanja modal ini menurut 
Halim (2008) dapat mendorong pertumbuhan ekonomi secara riil, karena infrastruktur yang dibiayai dengan belanja modal nantinya akan mempercepat roda perekonomian sehingga distribusi barang dan jasa dapat dilakukan dengan lebih efisien dan efektif.

\section{Hasil Pengujian Hipotesis}

\section{Pengaruh Langsung}

Dalam menganalisis pengaruh belanja pegawai, belanja barang jasa, belanja modal terhadap kemiskinan dengan pengangguran sebagai variabel intervening di Kota Banjarmasin.Berdasarkan hasil pengolahan data diperoleh nilai p-value sebagai pengukur tingkat signifikansi secara langsung (direct effect) yang dapat dijelaskan pada tabeldi bawah ini:

\section{Tabel 1}

\section{Signifikansi Pengaruh Langsung X1, X2 dan X3 Terhadap Z}

\begin{tabular}{|c|c|c|}
\hline \multirow[t]{2}{*}{ Model } & Standardized & \multirow[t]{2}{*}{ Sig. } \\
\hline & Beta & \\
\hline (Constant) & & .412 \\
\hline $\mathrm{X} 1$ & .714 & .165 \\
\hline$X 2$ & 1.275 & .037 \\
\hline X3 & -1.190 & .103 \\
\hline
\end{tabular}

Sumber : Data yang diolah (2021)

a. Analisis pengaruh $\mathrm{X} 1$ terhadap $\mathrm{Z}$ : Dari hasil analisis diatas diperoleh nilai signifikansi X1 sebesar 0,165 lebih besar dari 0,05. Sehingga dapat dsimpulkan bahwa secara langsung tidak terdapat pengaruh signifikan X1 terhadap Z

66 
b. Analisis pengaruh $\mathrm{X} 2$ terhadap $\mathrm{Z}$ : Dari hasil analisis diatas diperoleh nilai signifikansi X2 sebesar 0,037 lebih kecil dari 0,05. Sehingga dapat dsimpulkan bahwa secara langsung terdapat pengaruh signifikan X2 terhadap Z

c. Analisis pengaruh X3 terhadap Z : Dari hasil analisis diatas diperoleh nilai signifikansi X3 sebesar 0,103 lebih besar dari 0,05. Sehingga dapat dsimpulkan bahwa secara langsung tidak terdapat pengaruh signifikan X3 terhadap Z

Tabel 2

\section{Signifikansi Pengaruh Langsung X1, X2, X3 dan Z Terhadap Y}

\begin{tabular}{|c|c|c|c|}
\hline \multirow{2}{*}{\multicolumn{2}{|c|}{ Model }} & Standardized & \multirow[t]{2}{*}{ Sig. } \\
\hline & & Beta & \\
\hline \multirow{5}{*}{1} & (Constant) & & .010 \\
\hline & X1 & -.651 & .527 \\
\hline & $\mathrm{X} 2$ & -.676 & .628 \\
\hline & X3 & .935 & .540 \\
\hline & Z & .934 & .340 \\
\hline
\end{tabular}

Sumber : Data yang diolah (2020)

a. Analisis pengaruh $\mathrm{X} 1$ terhadap $\mathrm{Y}$ : Dari hasil analisis diatas diperoleh nilai signifikansi X1 sebesar 0,527 lebih besar dari 0,05. Sehingga dapat dsimpulkan bahwa secara langsung tidak terdapat pengaruh signifikan $X 1$ terhadap $Y$

b. Analisis pengaruh $\mathrm{X} 2$ terhadap $\mathrm{Y}$ : Dari hasil analisis diatas diperoleh nilai signifikansi X2 sebesar 0,628 lebih kecil dari 0,05. Sehingga dapat dsimpulkan bahwa secara langsung tidak terdapat pengaruh signifikan X2 terhadap $\mathrm{Y}$

c. Analisis pengaruh X3 terhadap Y : Dari hasil analisis diatas diperoleh nilai signifikansi X3 sebesar 0,540 lebih besar dari 0,05. Sehingga dapat dsimpulkan bahwa secara langsung tidak terdapat pengaruh signifikan X3 terhadap $Y$

67 
d. Analisis pengaruh $\mathrm{Z}$ terhadap $\mathrm{Y}$ : Dari hasil analisis diatas diperoleh nilai signifikansi Z sebesar 0,340 lebih besar dari 0,05. Sehingga dapat dsimpulkan bahwa secara langsung tidak terdapat pengaruh signifikan $\mathrm{Z}$ terhadap $\mathrm{Y}$

\section{Pengaruh Tidak Langsung}

a. Analisis pengaruh $\mathrm{X} 1$ melalui $\mathrm{Z}$ terhadap $\mathrm{Y}$ : diketahui pengaruh langsung yang diberikan X1 terhadap Z sebesar 0,714.Kemudian pengaruh tidak langsung X1 melalui $\mathrm{Z}$ terhadap $\mathrm{Y}$ perkalian antara nilai Beta $\mathrm{X}$ 1 terhadap $\mathrm{Z}$, dengan nilai Beta $\mathrm{Z}$ terhadap $\mathrm{Y}$ yaitu : $0,714 \mathrm{X} 0,934=0,666$. Maka pengaruh total yang diberikan X1 terhadap $\mathrm{Y}$ adalah pengaruh langsung ditambah dengan pengaruh tidak langsung yaitu: $0,714+0,666=1,380$. Berdasarkan hasil perhitungan diatas diketahui bahwa nilai pengaruh langsung sebesar 0,714 dan pengaruh tidak langsung 0,666 yang berarti bahwa nilai pengaruh tidak langsung lebih kecil di bandingkan dengan nilai pengaruh langsung, hasil ini menunjukkan bahwa secara tidak langsung X1 melalui $\mathrm{Z}$ tidak mempunyai pengaruh signifikan terhadap Y.

b. Analisis pengaruh $\mathrm{X} 2$ melalui $\mathrm{Z}$ terhadap $\mathrm{Y}$ : diketahui pengaruh langsung yang diberikan X2 terhadap Z sebesar 1,275. Kemudian pengaruh tidak langsung X2 melalui Z terhadap Y perkalian antara nilai Beta X2 terhadap Z, dengan nilai Beta $\mathrm{Z}$ terhadap $\mathrm{Y}$ yaitu : 1,275 X 0,934 = 1,190. Maka pengaruh total yang diberikan X2 terhadap Y adalah pengaruh langsung ditambah dengan pengaruh tidak langsung yaitu: $1,275+1,190=2,465$. Berdasarkan hasil perhitungan diatas diketahui bahwa nilai pengaruh langsung sebesar 1,275 dan pengaruh tidak langsung 1,190 yang berarti bahwa nilai pengaruh tidak langsung lebih kecil di bandingkan dengan nilai pengaruh langsung, hasil ini menunjukkan bahwa secara tidak langsung X2 melalui $\mathrm{Z}$ tidak mempunyai pengaruh signifikan terhadap Y.

68 
c. Analisis pengaruh $\mathrm{X} 3$ melalui $\mathrm{Z}$ terhadap $\mathrm{Y}$ : diketahui pengaruh langsung yang diberikan X3 terhadap Z sebesar -1,190. Kemudian pengaruh tidak langsung X3 melalui Z terhadap Y perkalian antara nilai Beta X3 terhadap Z, dengan nilai Beta $Z$ terhadap $Y$ yaitu : -1,190X 0,934 = -1,111. Maka pengaruh total yang diberikan X3 terhadap Y adalah pengaruh langsung ditambah dengan pengaruh tidak langsung yaitu: $-1,190+-1,111=-2,301$. Berdasarkan hasil perhitungan diatas diketahui bahwa nilai pengaruh langsung sebesar -1,190dan pengaruh tidak langsung -1,111 yang berarti bahwa nilai pengaruh tidak langsung lebih besar di bandingkan dengan nilai pengaruh langsung, hasil ini menunjukkan bahwa secara tidak langsung X3 melalui Z mempunyai pengaruh signifikan terhadap $\mathrm{Y}$.

\section{PEMBAHASAN}

\section{Belanja Pegawai Dapat Mengatasi Kemiskinan Di Kota Banjarmasin}

Hasil pengujian menunjukannilai sig Belanja Pegawai Terhadap Kemiskinan sebesar 0,527 sehingga dapat disimpulkan bahwa belanja pegawai tidak berpengaruh signifikan terhadap penurunan kemiskinan di Kota Banjarmasin. Yang artinya belanja pegawai pada tahun 2012 sampai dengan 2019 belum mampu mengatasi atau menurunkan angka kemiskinan di Kota Banjarmasin.

Hasil penelitian ini menunjukkan bahwa realisasi anggaran pada pos Belanja Pegawai tidak memiliki pengaruh terhadap tingkat kemiskinan dengan kata lain belum mampu sepenuhnya mengatasi kemiskinan di Kota Banjarmasin.Hal ini mengandung arti bahwa Belanja Pegawai yang diberikan selama ini oleh pemerintah Kota Banjarmasinuntuk kepentingan masyarakat, tidak secara langsung dirasakan oleh masyarakat kecil yang cenderung kurang mampu, sehingga belanja pegawai belum sepenuhnya dapat mengatasi kemiskinan.

\section{Belanja Barang Jasa Dapat Mengatasi Kemiskinan Di Kota Banjarmasin}


Hasil pengujian menunjukannilai sig Belanja Barang Jasa Terhadap Kemiskinan sebesar 0,628 sehingga dapat disimpulkan bahwa Barang Jasa tidak berpengaruh signifikan terhadap penurunan kemiskinan di Kota Banjarmasin. Yang artinya Belanja Barang Jasa pada tahun 2012 sampai dengan 2019 belum mampu mengatasi atau menurunkan angka kemiskinan di Kota Banjarmasin.

Hasil penelitian menunjukkan bahwa realisasi anggaran pada pos Belanja Barang Jasa tidak memiliki pengaruh terhadap tingkat kemiskinan dengan kata lain belum mampu sepenuhnya mengatasi kemiskinan di Kota Banjarmasin.Hal ini mengandung arti bahwa Belanja Barang Jasa yang diberikan selama ini oleh pemerintah Kota Banjarmasinuntuk kepentingan masyarakat, tidak secara langsung dirasakan oleh masyarakat kecil yang cenderung kurang mampu, sehingga Belanja Barang Jasa belum sepenuhnya dapat mengatasi kemiskinan.

\section{Belanja Modal Dapat Mengatasi Kemiskinan Di Kota Banjarmasin}

Hasil pengujian menunjukannilai sig Belanja Modal Terhadap Kemiskinan sebesar 0,540 sehingga dapat disimpulkan bahwa Belanja Modal tidak berpengaruh signifikan terhadap penurunan kemiskinan di Kota Banjarmasin. Yang artinya Belanja Modal pada tahun 2012 sampai dengan 2019 belum mampu mengatasi atau menurunkan angka kemiskinan di Kota Banjarmasin.

Hasil penelitian menunjukkan bahwa realisasi anggaran pada pos Belanja Modal tidak memiliki pengaruh terhadap tingkat kemiskinan dengan kata lain belum mampu sepenuhnya mengatasi kemiskinan di Kota Banjarmasin.Hal ini mengandung arti bahwa Belanja Modal yang diberikan selama ini oleh pemerintah Kota Banjarmasinuntuk kepentingan masyarakat, tidak secara langsung dirasakan oleh masyarakat kecil yang cenderung kurang mampu, sehingga Belanja Modal belum sepenuhnya dapat mengatasi kemiskinan. 


\section{Pengangguran Dapat Mengatasi Kemiskinan Di Kota Banjarmasin}

Hasil pengujian menunjukannilai sig Pengangguran Terhadap Kemiskinan sebesar 0,340 sehingga dapat disimpulkan bahwa Pengangguran tidak berpengaruh signifikan terhadap penurunan kemiskinan di Kota Banjarmasin. Yang artinya Pengangguran pada tahun 2012 sampai dengan 2019 belum mampu mengatasi atau menurunkan angka kemiskinan di Kota Banjarmasin.

Hasil penelitian menunjukkan bahwa segala kebijakan dengan tujuan penurunan tingkat pengangguran tidak memiliki pengaruh terhadap tingkat kemiskinan,dengan kata lain belum mampu sepenuhnya mengatasi kemiskinan di Kota Banjarmasin.Hal ini mengandung arti bahwa tingkatPengangguran yang diturunkan selama ini oleh pemerintah Kota Banjarmasinuntuk kepentingan masyarakat, tidak secara langsung dirasakan oleh masyarakat kecil yang cenderung kurang mampu, sehingga penurunan Pengangguran belum sepenuhnya dapat mengatasi kemiskinan.

\section{Belanja Pegawai Dapat Mengatasi Pengangguran Di Kota Banjarmasin}

Hasil pengujian menunjukannilai sig Belanja Pegawai Terhadap Pengangguran sebesar 0,165 sehingga dapat disimpulkan bahwa belanja pegawai tidak berpengaruh signifikan terhadap penurunan Penganggurandi Kota Banjarmasin. Yang artinya belanja pegawai pada tahun 2012 sampai dengan 2019 belum mampu mengatasi atau menurunkan angka pengangguran di Kota Banjarmasin.

Hasil penelitian menunjukkan bahwa realisasi anggaran pada pos Belanja Pegawai tidak memiliki pengaruh terhadap penganggurandengan kata lain belum mampu sepenuhnya mengatasi pengangguran di Kota Banjarmasin.Dimana dengan adanya penambahan alokasi belanja pegawaibelum mampu membuka kesempatan kerja yang lebih besar di kota Banjarmasin 


\section{Belanja Barang Jasa Dapat Mengatasi Pengangguran Di Kota Banjarmasin}

Hasil pengujian menunjukannilai sig Belanja Barang Jasa Terhadap Pengangguran sebesar 0,037, sehingga dapat disimpulkan bahwa Barang Jasa berpengaruh signifikan terhadap penurunan Penganggurandi Kota Banjarmasin. Yang artinya Belanja Barang Jasa pada tahun 2012 sampai dengan 2019 mampu mengatasi atau menurunkan angka pengangguran di Kota Banjarmasin.

Hasil penelitian menunjukkan bahwa realisasi anggaran pada pos Belanja Barang Jasa memiliki pengaruh terhadap penganggurandengan kata lain mampu sepenuhnya mengatasi pengangguran di Kota Banjarmasin.Dimana dengan adanya penambahan alokasi belanja Barang Jasamampu membuka kesempatan kerja di kota Banjarmasin

\section{Belanja Modal Dapat Mengatasi Pengangguran Di Kota Banjarmasin}

Hasil pengujian menunjukannilai sig Belanja Modal Terhadap Pengangguran sebesar 0,105 sehingga dapat disimpulkan bahwa Belanja Modal tidak berpengaruh signifikan terhadap penurunan Penganggurandi Kota Banjarmasin. Yang artinya Belanja Modal pada tahun 2012 sampai dengan 2019 belum mampu mengatasi atau menurunkan angka pengangguran di Kota Banjarmasin.

Hasil penelitian menunjukkan bahwa realisasi anggaran pada pos Belanja Modal tidak memiliki pengaruh terhadap penganggurandengan kata lain belum mampu sepenuhnya mengatasi pengangguran di Kota Banjarmasin.Dimana dengan adanya penambahan alokasi Belanja Modalbelum mampu membuka kesempatan kerja yang lebih besar di kota Banjarmasin.

\section{Belanja Pegawai Dapat Mengatasi Kemiskinan Melalui Pengangguran Di Kota}

\section{Banjarmasin}

Hasil pengujian menunjukannilai pengaruh langsung sebesar 0,714 dan pengaruh tidak langsung 0,666 yang berarti bahwa nilai pengaruh tidak langsung 72 
lebih kecil di bandingkan dengan nilai pengaruh langsung, hasil ini menunjukkan bahwa secara tidak langsung X1 melalui Z tidak mempunyai pengaruh signifikan terhadap $Y$, sehingga dapat disimpulkan bahwa belanja pegawai tidak berpengaruh signifikan terhadap penurunan Kemiskinan melalui Penganggurandi Kota Banjarmasin. Yang artinya belanja pegawai pada tahun 2012 sampai dengan 2019 belum mampu mengatasi atau menurunkan angka kemiskinan di Kota Banjarmasin jika melalui penurunan pengangguran.

Hasil penelitian ini menunjukkan bahwa realisasi anggaran pada pos Belanja Pegawai tidak memiliki pengaruh yang signifikan terhadap tingkat kemiskinan jika melalui penurunan pengangguran, dengan kata lain belum mampu sepenuhnya mengatasi kemiskinan di Kota Banjarmasin.Hal ini mengandung arti bahwa Belanja Pegawai yang diberikan selama ini oleh pemerintah Kota Banjarmasinuntuk kepentingan masyarakat, belum dapat secara langsung dirasakan oleh masyarakat kecil yang cenderung kurang mampu jika melalui penurunan pengangguran, sehingga belanja pegawai sudah sepenuhnya dapat mengatasi kemiskinan.

\section{Belanja Barang dan Jasa Dapat Mengatasi Kemiskinan Melalui Pengangguran}

\section{Di Kota Banjarmasin}

Hasil pengujian menunjukan nilai pengaruh langsung sebesar 1,275 dan pengaruh tidak langsung 1,190 yang berarti bahwa nilai pengaruh tidak langsung lebih kecil di bandingkan dengan nilai pengaruh langsung, hasil ini menunjukkan bahwa secara tidak langsung $\mathrm{X} 2$ melalui $\mathrm{Z}$ tidak mempunyai pengaruh signifikan terhadap Y. Yang artinya Belanja Barang Jasapada tahun 2012 sampai dengan 2019 belum mampu mengatasi atau menurunkan angka kemiskinan di Kota Banjarmasin jika melalui penurunan pengangguran.

73

Jurnal Komunikasi Bisnis dan Manajemen

Vol. 8 No. 2 Juli 2021 
Hasil penelitian menunjukkan bahwa realisasi anggaran pada pos Belanja Barang Jasatidak memiliki pengaruh signifikan terhadap tingkat kemiskinan jika melalui penurunan pengangguran,dengan kata lain belum mampu sepenuhnya mengatasi kemiskinan di Kota Banjarmasin.Hal ini mengandung arti bahwa Belanja Barang Jasa yang diberikan selama ini oleh pemerintah Kota Banjarmasinuntuk kepentingan masyarakat, tidak langsung dirasakan oleh masyarakat kecil yang cenderung kurang mampu jika melalui penurunan pengangguran, sehingga Belanja Barang Jasabelum sepenuhnya dapat mengatasi kemiskinan.

\section{Belanja Modal Dapat Mengatasi Kemiskinan Melalui Pengangguran Di Kota}

\section{Banjarmasin}

Hasil pengujian menunjukannilai pengaruh langsung sebesar $-1,190$ dan pengaruh tidak langsung -1,111 yang berarti bahwa nilai pengaruh tidak langsung lebih besar di bandingkan dengan nilai pengaruh langsung, hasil ini menunjukkan bahwa secara tidak langsung X3 melalui $\mathrm{Z}$ mempunyai pengaruh signifikan terhadap Y.

Hasil penelitian menunjukkan bahwa realisasi anggaran pada pos Belanja Modal memiliki pengaruh terhadap tingkat kemiskinan meskipun melalui penurunan pengangguran,dengan kata lain mampu sepenuhnya mengatasi kemiskinan di Kota Banjarmasin.Hal ini mengandung arti bahwa Belanja Modal yang diberikan selama ini oleh pemerintah Kota Banjarmasinuntuk kepentingan masyarakat, dapat dirasakan oleh masyarakat kecil yang cenderung kurang mampu, sehingga Belanja Barang Jasa sepenuhnya dapat mengatasi kemiskinan melalui penurunan tingkat pengangguran. 


\section{KESIMPULAN}

1. Belanja pegawai pada tahun 2012 sampai dengan 2019 belum mampu mengatasi atau menurunkan angka kemiskinan di Kota Banjarmasin.

2. Belanja Barang Jasa pada tahun 2012 sampai dengan 2019 belum mampu mengatasi atau menurunkan angka kemiskinan di Kota Banjarmasin.

3. Belanja Modal pada tahun 2012 sampai dengan 2019 belum mampu mengatasi atau menurunkan angka kemiskinan di Kota Banjarmasin.

4. Pengangguran pada tahun 2012 sampai dengan 2019 belum mampu mengatasi atau menurunkan angka kemiskinan di Kota Banjarmasin.

5. Belanja pegawai pada tahun 2012 sampai dengan 2019 belum mampu mengatasi atau menurunkan angka pengangguran di Kota Banjarmasin.

6. Belanja Barang Jasa pada tahun 2012 sampai dengan 2019 mampu mengatasi atau menurunkan angka pengangguran di Kota Banjarmasin.

7. Belanja Modal pada tahun 2012 sampai dengan 2019 belum mampu mengatasi atau menurunkan angka pengangguran di Kota Banjarmasin.

8. Belanja Pegawai pada tahun 2012 sampai dengan 2019 belum mampu mengatasi atau menurunkan angka kemiskinan jika melalui penurunan pengangguran di Kota Banjarmasin.

9. Belanja Barang Jasa pada tahun 2012 sampai dengan 2019 belum mampu mengatasi atau menurunkan angka kemiskinan jika melalui penurunan pengangguran di Kota Banjarmasin.

10. Belanja Modal pada tahun 2012 sampai dengan 2019 mampu mengatasi atau menurunkan angka kemiskinan meskipun melalui penurunan pengangguran di Kota Banjarmasin. 


\section{DAFTAR PUSTAKA}

Badan Pusat Statistik, 2019

Bloom, Canning, Fink, \& Finlay, 2007, Fertility, Female Labor Force Participation, and the Demographic Dividend

Chandrasekhar, Ghosh, Roychowdhury, 2006, The 'Demographic Dividend' and Young India's Economic Future

Gribble \& Bremner. (2012). Achieving A Demographic Dividend. Population Reference Bureau

Kuncoro, Mudrajad.2007. Metode Kuantitatif: Teori dan Aplikasi Untuk Bisnis dan Ekonomi. Yogyakarta: UPP STIM YKPN

Mankiw, N.Gregory. 2007. Makroekonomi, Edisi Keenam. Jakarta : Erlangga

Mulyadi. 2014. Sistem Akuntansi. Cetakan Keempat. Jakarta : Salemba Empat

Noor, J. (2015). Analisis Data Penelitian Ekonomi \& Manajemen. Jakarta: Grasindo.

Lembaga Demografi FEUI, 1981, Dasar-Dasar Demografi. Lembaga Penerbit FEUI. Jakarta

Silvia Sely Murthy, 2014, Analisis Rantai Nilai Dan Strategi Pengembangan Industri Kreatif Di Kota Bandung Dan Cimahi

Shenglong Liu, a. H. (2013). Demographic Change and Economic Growth: Theory and Evidence from China. Economic Modelling , 71-77

Sukirno, Sadono, 1996. Pengantar Teori Makro Ekonomi . PT Raja Grafindo. Jakarta

Sunyoto, D. (2012). Metode Analisis Jalur Untuk Riset Ekonomi. Bandung: Yrama Widya.

United Nations, Department of Economic and Social Affairs, Population Division (2015). World Population Prospects: The 2015 Revision, Methodology of the United Nations Population Estimates and Projections, Working Paper No. ESA/P/WP.242

WorldBank, 2018

76

Jurnal Komunikasi Bisnis dan Manajemen

Vol. 8 No. 2 Juli 2021 
Zefri Mario Sandy Indrawan, 2018, Analisis Bonus Demografi Dan Pertumbuhan Ekonomi Di Indonesia 